\title{
SALAZAR'S INTERFERENCE IN THE BBC PORTUGUESE SERVICE DURING WORLD WAR II
}

\section{Nelson Ribeiro}

\begin{abstract}
:
This article presents a case study on the limits of the BBC Overseas Service's journalistic independence during World War II. Not only editorial policy but also the personnel hired by the BBC Portuguese Service were subject to pressure from Salazar through the Foreign Office. How the Lisbon government was made aware of the events taking place inside the Portuguese Service and which strategies were used to interfere in its editorial line are discussed. This history presents clear evidence of how the BBC was required to trim its output in order to avoid diplomatic problems arising between the British and the Portuguese governments.
\end{abstract}

KEYWORDS: BBC Overseas Service; Estado Novo; Oliveira Salazar; Transborder broadcasts

\section{Introduction}

British shortwave broadcasts in Portuguese to Portugal started on 4 June 1939 and were monitored very carefully by Oliveira Salazar's dictatorship (known as the Estado Novo - or "New State" in English). The Portuguese authoritarian regime was different to all others since the Head of Government did not see the State as an omnipotent entity. The arrangement was that the State's power should be limited by Catholic morals so that, unlike Nazism, it would not be permeated with an "aggressive, excessive, hateful nationalism" (Salazar, 1937, p. 285). Even so, the Estado Novo was marked by weak liberal 
principles and strong corporatist and authoritarian elements (Pinto, 2005, p. 26) which led Braga da Cruz to define it as "a baptised fascism" (Cruz, 1980, p. 306). Although the Constitution approved in 1933 established a series of rights, including the freedom of expression, individual rights were in practice always very limited and censorship was used to avoid the dissemination of ideas that were not in accordance to the regime's ideology.

Salazar was partially responsible for the BBC's enormous success in Portugal. If it had not been for his censorship-based media policies the public could have relied on news aired by the local stations or published in the local press. However, since both newspapers and radio stations only reported the news permitted by the censors, a thirst for more news was created and it could only be satisfied by listening to foreign stations and of those broadcasting to Portugal the BBC was "by far the most popular" (Foreign Office internal report, 1944, National Archives, FO 371/39616).

The huge success of the BBC in Portugal, which can be attributed to its high level of credibility and to a basic Anglophile sentiment among the Portuguese, led the Lisbon regime to carefully scrutinise the content of the broadcasts. The Embassy in London was particularly active in maintaining good contacts inside the BBC and in making suggestions regarding its editorial line.

\section{The Case of Armando Cortesão}

The dismissal of the anti-Salazar political refugee Armando Cortesão from the BBC is the most egregious example of Salazar's interference in the Portuguese Service. After a period working for the Brazilian section, Cortesão had become a translator in the Portuguese Section in 1941 and was also responsible for editing some of the scripted talks aired on the broadcasts (Foreign Office memorandum, October 1941, National Archives, FO 371/26819). In addition, besides his work at the Corporation, he regularly wrote for the Lisbon magazine Seara Nova, in which his articles were frequently censored. ${ }^{1}$ He quickly became a scapegoat used by the Lisbon government to demand a change in the editorial line of the BBC's Portuguese Service. 
The Estado Novo's concern with the role of Armando Cortesão inside the BBC existed prior to the launch of the Portuguese Service. In a letter addressed to Salazar, on 3 March 1939, the Ambassador in London, Armindo Monteiro, openly expressed his fear that Cortesão would become a staff member of the Portuguese Service. Known for his opposition to the Estado Novo's ideology, Cortesão had been sentenced in absentia in 1934 (Diário da Manhã, 1941a) for the attempted overthrow of Salazar. He was among a group of more than one thousand anti-fascist Portuguese of the political and military elites who sought exile in Spain. His brother Jaime Cortesão, besides being a highly regarded intellectual, was "the favoured orator of the Spanish republican authorities, the 'voice' of the Portuguese exiles against the Salazar regime" (Oliveira, 1987, p. 228). ${ }^{2}$

By March 1939, Cortesão was already working at the Brazilian Section; and the possibility of his transition to the Portuguese Service that was then being organized worried Armindo Monteiro:

It would be no surprise if the B.B.C., in regard to the case of direct interest to us, and for economic reasons, just tried to expand the services of its Brazilian section. Employed in that section, and in a position of some prominence [...] sheltered by the B.B.C.'s own leftwing tendencies, is the Portuguese political refugee Armando Cortezão, the infamous editor of a notorious secret pamphlet totally filled with lies [...]. I don't really know if the British, with their usual incomprehension of the political intricacies of other peoples, will now comprehend the gaffe that they would commit by placing in a position of prominence in a news service intended to capture the support of a certain people and a certain government... a political refugee of such moral perfection! Let's hope that they understand (Letter from Monteiro to Salazar, 3 March 1939, Historic Diplomatic Archive, M.97 CP).

It was in response to this letter that Salazar himself asked Monteiro to express to the Foreign Office the dim view the Lisbon government would take 
of the appointment of Cortesão to the Portuguese Section. In reply, the Chief of the News Department of the Foreign Office guaranteed that the new Service would not be run by Cortesão (Historic Diplomatic Archive, M.97 CP and M.248 $\mathrm{CP}$ ). At the time, this response was considered to be sufficient by the Portuguese government. Nevertheless, during 1941 when Cortesão was responsible for the translation of a broadsheet in Portuguese which advertised the $\mathrm{BBC}$ programmes, his presence inside the Corporation gave rise to a serious diplomatic incident. The BBC was well aware of the fact that the employment of Cortesão was a very sensitive matter which explains an internal discussion that took place in April and May 1941 about the possible transfer of Cortesão to the Overseas Publicity section; but this did not occur (BBC Written Archives, R13/199/2).

A few months later, in September, there were rumours regarding the possibility of Cortesão being put in charge of the Portuguese Service ${ }^{3}$ which again irritated Salazar and his government. Moreover, the rumour was spread during a very sensitive period for British propaganda efforts since Hitler's invasion of Russia had been well received by some of the more conservative Portuguese elites. It was a particular easy time for rumours against the Corporation.

Due to his past and his political ideas, Cortesão was known for disagreeing with the friendly tone that the $\mathrm{BBC}$, in accordance to the British government's policy, had adopted in regards to the Estado Novo. ${ }^{4} \mathrm{He}$ was known to have written to some of his friends in Portugal urging them "to criticise the BBC's policy, in the hope that it will be modified in a sense unfavourable to Dr. Salazar" (Foreign Office report, October 1941, National Archives, FO 371/39616). Some of these letters had been intercepted by the political police in Lisbon, making the regime even more concerned about his influence inside the BBC.

The Foreign Office was, at the time, well aware of the starting point for the storm that then developed. In October, the Foreign Office notified the BBC of its concern regarding 'the Portuguese authorities' resentment of the employment of the political exile, Dr. Cortesão" (Letter from Roberts (F.O.) to Kirkpatrick (BBC), 29 October 1941, National Archives, FO 371/26819). The 
timing of this storm was also bad on the domestic front in Portugal, since local council elections were scheduled to take place on 19 October and, obviously, the regime became even less tolerant of anyone expressing ideas that were not in accordance with the status quo.

Salazar himself instructed the censors to suppress all agency messages that contained any kind of British propaganda, which led to a change in the newspapers tone. The press had been receiving a combined Reuters and Exchange Telegraph service since August 1941, which meant that the quantity and quality of the messages received and published from British sources had grown considerably (Letter from Munro (Ministry of Information) to Markins (F.O.), 12 February 1942, National Archives, FO 371/31113). Nevertheless, following the instructions given by the Head of the Government, the efficiency of the censors, in terms of suppressing messages of British origin, became very apparent. A telegram from the Embassy in Lisbon to the Foreign Office testifies how radical this suppression was by the month of October:

\begin{abstract}
Censorship during the past five days has banned British photographs and severely cut the British news service. Censor told the Press Attaché that this action had been taken on direct instructions from Salazar who wishes thus to mark his resentment at "the change of tone of the BBC's Portuguese transmissions". In reply to enquiry in what respect there had been change, the Censor said that there had of late been noticeable absence of any complimentary reference to the Portuguese Government and he went on to speak of Portuguese exile in London, named Cortesão, employed as translator by the BBC (Telegram from Balfour (British Embassy) to F.O., 15 October 1941, National Archives, FO 371/26819).
\end{abstract}

The case of Armando Cortesão was made known to the Portuguese public through an editorial published in the semi-official newspaper Diário da Manhã, on 11 October. Carried on the front page, the text very strongly criticized those who, calling themselves Portuguese, were using foreign 
propaganda to attack the Estado Novo. Despite never mentioning the name of Cortesão it was evident that his presence at the BBC was the reason for the article:

Portugal has been [...] the victim, on some occasions, of pollution from those sources of foreign propaganda. But we have found in such cases, which are certainly few and far between, that they are almost always due to the abusive intervention of agents with malicious intent who, for reasons of sedition or resentment, seek to politically, economically and morally discredit us [...]. Some of those agents present themselves under Portuguese names [...]. We do not want to believe that there are Portuguese, with such privileged names, capable of using radio, foreign news agencies or press to attack the Government and the institutions, or to give a false impression of the people and their country (Diário da Manhã, 1941b).

This article, along with the instructions given to the censors to suppress news from British sources, led Marcus Cheke, Press Attaché of the British Embassy in Lisbon, to speak directly to the Head of Censorship, Major Álvaro Barreto. During the conversation, which took place on 14 October, Cheke explained that Cortesão did not have any influence in the editorial orientation of the BBC broadcasts, since he was merely a translator. This, however, was not enough to bring the incident to an end and the Portuguese press continued to write about the matter. On 17 October, O Século published an article on its front page which commented on the harm that anti-Portuguese propaganda could have. It never mentioned the Cortesão case or the BBC, but for readers who knew of the situation it was clear that the article was criticizing some of the BBC's features broadcast to Portugal.

With the help of the press, the Estado Novo managed to create the perception in a section of public opinion that it was owing to Cortesão's influence that the Corporation was now addressing issues in its Portuguese 
Service that were not well received by the regime, namely news and comments on Russia (O Século, 1941) considered a sensitive matter for the Lisbon regime due to its anti-communist ideology. By combining the usage of the press, direct censorship and diplomatic pressure the Estado Novo tried to influence the British broadcasts to Portugal. Its aim was not only to accomplish the dismissal of Cortesão but also to influence the overall tone of the broadcasts and remove material it did not like.

The censorship became so severe in blocking British news and photographs that it was not long before the Embassy in Lisbon suggested that the BBC should give in to Salazar's demand and dismiss Armando Cortesão. The requests to the Foreign Office on this matter were quite insistent:

I consider that in the light of the incident the BBC would be well advised to respond as soon as possible to the recommendations recently made by the Press Office that they should cease to employ Cortesão in any capacity (Telegram from Balfour (British Embassy) to F.O., 15 October 1941, National Archives, FO $371 / 26819)$.

Following this recommendation the Ministry of Information confirmed that it was "endeavouring to remove Dr. Cortesão from the BBC" (Letter from McCann (Ministry of Information) to Markins (F.O.), 17 October 1941, National Archives, FO 371/26819). In the meanwhile, despite all the guarantees that were given about the non-interference of Cortesão on the editorial line of the Portuguese Service, his mere presence at the BBC was enough for Monteiro to suspect that the Corporation was intending to tinge its broadcasts "with hostility towards the $[. .$.$] regime in Portugal" (Ibidem).$

Salazar acted on this information and, besides excising news from British sources he continued to use the press to disseminate information that harmed the BBC's credibility in Portugal. On 20 October the Diário da Manhã readdressed the case, this time in more violent terms. Cortesão was described as an enemy of the Estado Novo who was using a foreign broadcaster to attack 
the Portuguese regime (Diário da Manhã, 1941c). Four days later the same newspaper published another front page editorial accusing the Portuguese Service of being steered by an enemy of the Estado Novo:

[Foreign propaganda] is, if not managed or steered, then at least interfered with or manipulated by known and declared enemies of the Estado Novo. We would not be true to ourselves if we were not to publicly declare our astonishment in view of certain facts that have sadly been verified and confirmed (Diário da Manhã, 1941a).

As the Embassy in Lisbon had informed the Foreign Office, flattery was very important to the Portuguese regime and this had also been "forgotten" by the BBC broadcasts. This was another argument used by Diário da Manhã to conclude that the service was being run by an opponent of the Portuguese regime.

The article also presented a profile of Armando Cortesão, stating that he was a "well known enemy of the Estado Novo" who had been behind several attempts to overthrow the regime. Moreover, his character was attacked as he was accused of having committed several frauds and stealing money from his own brother and from funds that were destined to emigrants living in Corunha (Spain):

From a moral viewpoint, Mr. Armando Cortesão, besides conspiring against a State for which he worked as an important civil servant, was accused by some emigrants of having used funds for revolutionary purposes or to aid the families of exiles for personal expenses. [...] His political friends also complain that when his brother Jaime Cortesão was in exile [...] the careful Armando lent him various sums of money with written receipts and then took possession of his goods to settle the debts, leaving his brother penniless. [...] This is enough to show the moral and 
political fibre of the man intending to direct or steer a Portuguese section of the BBC in London from behind the curtain! (Ibidem)

This article, openly mentioning Cortesão's interference in the BBC's editorial line, motivated a severe protest from the British authorities which demanded that a denial be published the following day:

His Majesty's Embassy in Lisbon communicates the following: "The Diário da Manhã newspaper of the $24^{\text {th }}$ of this month published an article containing news that it claims to be widely disseminated, this being that Dr. Armando Cortesão has been placed in charge of the BBC's Propaganda Section for Portugal. This news article is, however, devoid of any foundation. Mr. Cortesão has never had any influence in the organisation of the BBC's programmes for Portugal" (Diário da Manhã, 1941d).

The text was printed on the front page, followed by a comment of the newspaper in which Diário da Manhã mentioned its own satisfaction at the fact that Cortesão was not in charge of the Portuguese Section. But, in any case, it added that "some attitudes of the BBC concerning Portugal remain to be explained" (Ibidem).

The issue was addressed during the Corporation's evening transmission to Portugal. The station presented an explanation and assured that Cortesão was merely a translator and therefore did not interfere in the editorial content of the broadcasts:

[...] We categorically declare that Dr. Cortezão does not occupy any post in the Portuguese Section of the B.B.C. other than that of translator. Moreover, he has never had, at any time, any active voice in the management of the news or the programmes broadcast to Portugal (Transcription of the BBC news bulletin to 
Portugal, 25 October 1941, Oliveira Salazar Archive, AOS/CO/PC-3E).

In the meanwhile, this situation was being exploited by German propaganda which was including "small complimentary references to the Portuguese government" (Telegram from Balfour to F.O., 18 October 1941, National Archives, FO 371/26819) in its broadcasts in order to create the idea that unlike London, Berlin had friendly relations with the Portuguese regime. The Berlin station accused the BBC of promoting personalities who only aimed to overthrow Salazar and his regime:

Only a few days ago the Diário da Manhã, your governmental daily newspaper, complained that English propaganda broadcast in Portuguese was giving shelter to [...] a Portuguese emigrant, traitor to the fatherland, who entertains himself, as your well regarded newspaper so states, by spreading, lies [...] against Salazar's Government and against the Estado Novo (Transcription of the German broadcast to Portugal, 27 October 1941, Oliveira Salazar Archive, AOS/CO/PC-3E).

As the suppression of news of British origin continued, the representative of the Exchange Telegraph in Lisbon contacted the Head of Censorship asking him to revise his attitude. The same request was made by the British Embassy in its contacts with the Lisbon authorities. The British Ambassador, Sir Ronald Campbell, though, considered that the solution for this diplomatic conflict should necessarily involve the dismissal of Armando Cortesão. He talked personally with Salazar on 29 October explaining his surprise and shock at the way the British news was being treated just because "an obscure employee of the British Broadcasting Corporation had written one or two foolish letters to his friends in Portugal" (Telegram from Campbell to Ministry of Information, 30 October 1941, National Archives, FO 371/26819). Salazar did not deny that he himself had ordered the Censor to cut as much British news as possible and he 
even surprised Sir Ronald by stating that this was a response to a similar policy that was being followed by the London government:

Dr. Salazar said that [...] he had learnt that instructions had recently been given both to the English press and to the British Broadcasting Corporation to adopt a less friendly tone towards Portugal. He had therefore taken the step which I had described as Portugal would otherwise have been guilty of servility. When I had recovered from my amazement at this fantastic but typically Portuguese notion I replied that there must be some misunderstanding as I was quite certain that no such instructions as he had referred to had been given. [...] Can you furnish me with some categorical denial which will help me to bring this ridiculous incident to an end? (Ibidem)

This idea expressed by Salazar, that the BBC, following instructions from the British government, had supposedly decided to adopt a less friendly tone towards Portugal, mainly arose because of the incident with Cortesão. He had history with Armindo Monteiro, when the latter had held the post of Colonial Secretary and the former worked as highly-ranked civil servant under him. A few months before the diplomatic incident arose, Cortesão had written a letter to Salazar in which he offered his services to help in the promotion of the AngloPortuguese relations. Later on, on 13 August 1941, he asked to be received by Monteiro, whom he intended to inform of the letter sent to the Head of Government. However, the Ambassador refused to grant him an audience, which was considered by Salazar to be the correct response (Letter from Monteiro to Salazar, 14 August 1941, Historic Diplomatic Archive, M.151 CP). A few days later, Cortesão wrote to Monteiro lamenting his attitude (Letter from Cortesão to Monteiro, 16 August 1941, Historic Diplomatic Archive, M.151 CP). This letter, which must have irritated the Ambassador, made him more sensitive than ever to information concerning Cortesão's role inside the BBC. Combined with the information that he would be put in charge of the Service and the 
German invasion of Russia, Monteiro was even more irritated. This confluence of events and attitudes explains the timing of this crisis.

Cortesão was dismissed from the BBC on December 1941 as a result of all the political pressure. The matter was analysed at the Foreign Office and the Ministry of Information which had a direct interference in the foreign languages broadcasts since, unlike the Home Service, these were "financed not by the licence fee but by a direct grant from the Treasury" (Winston, 2005, p. 286). Both ministries agreed that it was "most undesirable that officials of the British Broadcasting Corporation should organise opposition to any policy which the Corporation is following on the instructions of His Majesty's Government" (Letter from Ministry of Information to Under-Secretary of State F.O., 3 November 1941, National Archives, FO 371/26819). At first the BBC did not accept the idea of dismissing Cortesão because he "was merely a translator of a broadsheet in Portuguese which advertises the BBC programmes and contains, in addition, a certain amount of reading material" (Ibidem). The Corporation also alleged that if Cortesão was removed immediately from the service the broadsheet would have to be discontinued (Letter from BBC to Radcliffe (Ministry of Information), 1 November 1941, BBC Written Archives, E2/490). Nevertheless, despite this resistance to governmental interference, replacements for Cortesão were arranged (Telegram from Campbell to F.O., 22 November 1941, National Archives, FO 371/26819) through the British Embassy in Lisbon and he was officially dismissed on 4 December (Telegram from Cortesão to Casimiro, 18 December 1941, National Archives, FO 371/26819).

The BBC made no arguments as regards its independence but the Minister of Information was subsequently questioned in the House of Commons regarding the independence of the staff working at the Portuguese Section of the $\mathrm{BBC}$ at that time. According to Armindo Monteiro, "Mr. Cortezão made it known that the BBC's current employees responsible for broadcasts in Portuguese are "fascists" and he found a way for a member of parliament to ask a question on the subject in Parliament" (Letter from Monteiro to Salazar, 31 December 1941, Historic Diplomatic Archive, M.176C CP). This took place on 19 December: 
Mr. Ness Edwards asked the Minister of Information whether he will investigate both the nature of the broadcasts in Portuguese and the antecedents of those employees of the British Broadcasting Corporation responsible for these broadcasts? Mr. Thurtle - If my hon. Friend will be good enough to give me some more specific indication of the matters he has in mind I will cause inquiries to be made into them (Hansard parliamentary debates).

The effect of this question was null and therefore Cortesão remained dismissed.

\section{Control over the Staff and Editorial Interference}

The intervention of the Lisbon authorities into the case of Armando Cortesão did not come as a surprise since from the start of the Service the British had allowed Portuguese interference via the Ambassador in London. He had cultivated good relations with those who worked at the BBC Portuguese Section. Moreover, only a few days following the official inauguration of the broadcasts to Portugal, the Lisbon regime had helped the BBC to solve a serious problem concerning the transmissions: the lack of qualified people available to work at Bush House with a good knowledge of both English and Portuguese. Following a request from the Ministry of Information in London Salazar had authorised three Portuguese civil servants to work as translators at the BBC (Letter from Director of the Foreign Publicity Directorate (Ministry of Information) to Monteiro, 10 September 1939, Historic Diplomatic Archive, M.97 $\mathrm{CP}$ ). This was a subtle way for the Estado Novo to maintain some leverage on the content of the broadcasts since it retained the possibility of calling the translators back to Lisbon, which could jeopardise the Portuguese Service.

Later on, during 1941, the Chancellor of the Embassy was also one of the BBC translators. Commenting on this situation, which was a surprise even for Salazar, Ambassador Monteiro pressed the advantages of having a loyal person working in the Corporation: 
[...] I could not remain indifferent to the fact that such a situation might allow me to know in certain detail what was going on in the B.B.C. The Chancellor has shown total loyalty to the Embassy. It would be patently to our detriment to sever his connection to the B.B.C. [...]. We would lose a source of information that has proven to be useful (Letter from Monteiro to Salazar, 31 October 1941, Historic Diplomatic Archive, M.143 CP).

Salazar agreed that it was important strategically to maintain privileged sources of information on what was taking place inside the BBC and the Portuguese Section in particular. During the following year, Mrs. Frank Collin joined the BBC which also pleased Armindo Monteiro. An admirer of Salazar, she was an open advocate of the Estado Novo (Letter from Monteiro to Salazar, 15 May 1942, Historic Diplomatic Archive, M.76C CP) and a Portuguese speaker.

In accordance with the policy of remaining on good relations with all those working in the Portuguese Section, Monteiro wrote to Salazar in 1942 alerting the Portuguese authorities to a visit that Michael Winch, editor of the Portuguese Section, was scheduled to make to Portugal. He had taken the Service over at the end of the previous year:

On leaving here he shall be placed in the care of the British Embassy. I think it might be necessary to attract his attention towards the Portuguese institutions, which may be able to generate a favourable impression in him, thus ensuring that he is not solely left abandoned to British influence. [...] In the telegram I sent a few days ago I also mentioned that Mr. Winch was a figure deserving of the care of the National Propaganda Secretariat. The presence of the Secretariat should, in my view, ensure it interacts with him in a very discrete fashion, providing useful information but not seeking to captivate or control him. Mr. Winch is quite English in his manner: he is therefore horrified at propaganda and naturally believes it to solely be a means of moulding facts and 
ideas so as to give them the perspective most convenient to the interested party at that time. It would be important for Mr. Winch to return as our friend and interested in Portugal and the accomplishments of the regime (Letter from Monteiro to Salazar, 6 October 1942, Historic Diplomatic Archive, M.76C CP).

This level of interest in Michael Winch was not untypical given the editorial power the editors of the different BBC foreign services were deemed to exercise. Despite efforts to make the European Service act in accordance with agreed principles and lines, such was not the case most of the time. This is clearly recognized in a BBC internal directive which states that "not only do some editors follow their own line, but they actually adopt a line directly contrary to that which had been laid down" (Directive of 18 June 1942, quoted in Bennett, 1966, p. 83). Moreover, according to Asa Briggs, all members of staff, in addition to the editors, had some influence in the selection of news "and many of them had their own sense not only of what broadcasting could and could not do in a protracted war of what mattered and did not matter." (Briggs, 1970, p. 482).

This explains Monteiro's interest in maintaining good relations with all the members of the Portuguese Service, from the editors to typists. Of course, the announcers were also an interesting target for the Embassy because even when reading the news and talks written by British journalists and commentators in translation, their voice inflexions partially determined the meaning of the texts.

Besides the good contacts that the Portuguese Ambassador maintained inside the BBC, the Portuguese Service was also infiltrated by Salazar's supporters, namely Colonel Egerton who was one of the first British authors to produce scripts aired in the broadcasts to Portugal. His links with the Estado Novo preceded the outbreak of World War II. In 1939 he spent four months in Portugal, during which time he developed contacts with the main personalities of the regime. His trip took place after his recommendation by Armindo Monteiro, who considered him to be a friend of the Estado Novo. ${ }^{5}$ Following this visit Colonel Egerton wrote a book praising the Salazar regime. Entitled Recreation, Revolution or Re-Birth, it was published in Lisbon in 1940. 
In February 1941 Egerton returned to Portugal. He stayed until May of the same year, collecting information for a second book. This visit was financially supported by the Portuguese Embassy in London and was organized by the National Propaganda Secretariat. It was after this trip that Colonel Egerton started to write scripts for the Portuguese Service on his return to London. Later on, he completed a new book on the Estado Novo, published immediately after the Azores Agreement in 1943, and titled Salazar, the Rebuilder of Portugal.

The presence of Colonel Egerton inside the Portuguese Section was very convenient for the Portuguese authorities. Not only were his scripts flattering to the Salazar regime but he also kept the Portuguese Embassy informed of what was happening inside the BBC and even inside the Ministry of Information, with which he also maintained regular contact.

Notwithstanding the good relations that the Estado Novo authorities maintained with members of the BBC Portuguese Service, the broadcasts earned the trust of the majority of the local listeners and were considered a highly credible source. Its success is confirmed in several reports assessing the Service's effectiveness, produced by the Foreign Office and the BBC (Ribeiro, 2005 , p. 218). ${ }^{6}$ The reports' conclusions are reinforced by a number of sources; for example, Artur Agostinho, one of the most popular Portuguese announcers who worked for several Lisbon radio stations during the war:

The BBC had a large audience. It had a lot of impact. It was listened to a lot. [...] German broadcasts never had a large audience and had, compared to the BBC, much less influence. [...] The BBC was deemed to be the "voice of truth". [...] It had a great deal of credibility. [...] BBC meant "you can believe it" and the BBC's impact was very different to that of the German broadcaster which, as a matter of fact, was hardly listened to in Portugal (Artur Agostinho, interview, 9 June 2006).

This trust was somewhat displaced because the Portuguese Ambassador actually succeeded in some of his attempts to interfere in the 
editorial line of the broadcasts. Not only did he demand, more than once, that the BBC flattered Salazar and his regime, but he also suggested that news concerning Russia and the Eastern front should not receive much attention on the broadcasts to Portugal:

The general tone and atmosphere of the references to the Soviet Union gave an impression of sympathy towards the Soviet Union which Portuguese opinion found difficult to understand. They realised that Great Britain should do everything possible to help a nation which was fighting their enemy; but Great Britain was not a communist country and the Prime Minister had said that he withdrew none of the things he had said against communism, nevertheless our broadcasts seemed to imply a deep feeling not merely for Russia, but for communist Russia (Minute of a conversation between Monteiro and Strang, 1 October 1941, National Archives, FO 371/26819).

Sir Ronald Campbell also wrote several letters to the Foreign Office in which he warned of the consequences that too much news on Russia might have on Salazar's relations with the British authorities in Portugal. Sir Ronald had also advised the Foreign Office to make arrangements to prevent the BBC from addressing issues that would irritate Salazar. One of his recommendations was that the word "democracy" should not be aired on the Portuguese Service:

\footnotetext{
Above all in all broadcast talks we must avoid the word "democracy". It is interpreted here as an incitement to the forces of disorder (Letter from Campbell to Strang, 12 May 1941, National Archives, FO 371/26818).
}

The Portuguese Service had the difficult task of balancing the defence of democracy and British values with the need to not create a diplomatic crisis with the Lisbon government. This balance that the BBC tried to achieve was a 
difficult one. On several occasions talks that had been broadcast on other European services concerning international current affairs were edited for transmission on the Portuguese Service (BBC Survey of European Audiences - Portugal, 30 September 1943, BBC Written Archives, E2/198). The specific need to preserve good relations with the Lisbon regime also led the station not to broadcast several items referring to social instability or disturbances that took place in Portugal during the war years.

Thus, although some criticisms from Armindo Monteiro were directly resisted, (Letter from F.O. to Kirkpatrick (BBC), 29 October 1941, BBC Written Archives, E2/490) after the Armando Cortesão crisis, the Foreign Office and the Ministry of Information did produce a "Guiding Line for Broadcasts to Portugal" which made a clear recommendation for the Service to avoid selecting items that would be "gratuitously offensive to the Portuguese government or Portuguese listeners or which could be interpreted as interference in Portuguese internal affairs" (BBC internal "Guiding line for Broadcasts to Portugal", 7 November 1941, National Archives, FO 371/26819). Moreover, British diplomacy now paid attention to the political orientation of the current members of the Service. Diplomats were fearful that some of the staff would be critical of Salazar. However, the Foreign Office was placated by the Foreign Adviser of the BBC, Ivone Kirkpatrick, who assured it that those working at the Portuguese Service were "mainly in sympathy of Salazar" (Letter from Kirkpatrick (F.O.) to Markins (BBC), 24 December 1941, National Archives, FO 371/26819).

\section{Conclusion}

The BBC Portuguese Service was attentively monitored by the Lisbon authorities, who, from the beginning, tried to influence content as much as possible, by suggesting people to be employed as staff and by cultivating close relations with many of those who worked for the Service. The Portuguese Ambassador in London was very focused on the BBC broadcasts. Besides being invited to speak at the microphone on a number of occasions, he 
regularly complained about the service's editorial line and his remarks were discussed inside the Foreign Office and the Ministry of Information.

In October 1941, when the rumour spread that a Portuguese political exile would be put in charge of the BBC's broadcasts to Portugal, Salazar used that case to pressurise the Corporation into returning to a path more favourable to his own regime. The Portuguese government used the Armando Cortesão case as a pretext to instruct the press not to publish any news from British sources and to impose strong control over propaganda activities throughout the country. The situation became unbearable for the British Embassy and it did not take long for Cortesão's dismissal to be recommended by the Foreign Office, proving that Salazar's policy of infiltration and influence received the blessing of the British government on several occasions.

The Cortesão crisis led to the adoption of new guidelines for the Portuguese Service, which clearly stated that news should not be offensive to the Lisbon government and that flattery of Salazar was once again recommended. By creating a direct relationship between the level of freedom given to British propaganda and their own satisfaction with the news and talks aired by the Portuguese Service, the Portuguese regime managed to interfere in the content of the broadcasts and ensured that the BBC did not become critical of the Estado Novo.

Salazar's indirect interference in the BBC through the Foreign Office clearly reveals the existence of a central paradox in the Portuguese Service. Promoted and trusted by listeners for being truthful in opposition to the German broadcasts, the BBC was actually infiltrated and influenced by the Salazar regime and, on several occasions, trimmed its output to meet considerations imposed by the Foreign Office.

The BBC's factual reporting might have been less tainted than any other source available to the Portuguese, but it was less independent than listeners believed. Crucially, the BBC's potential as a voice for democracy was not pursued. In fact, contrary to the wishes of those who in Portugal listened to the BBC and expected the British to impose democracy in the country after the war, this was not the policy of the Foreign Office. Far from falling at the end of the 
war Salazar remained in power for decades. The BBC Portuguese Service was scrapped in 1957, only to be revived six years later. It continues to broadcast.

\section{References}

Bennett, Jeremy (1966). British Broadcasting and the Danish Resistance Movement 1940-1945: a Study of the Wartime Broadcasts of the B.B.C. Danish Service, Cambridge: Cambridge University Press.

Briggs, Asa, (1970). The History of Broadcasting in the United Kingdom, Vol. III:

"The War of Words", Oxford: Oxford University Press.

Cruz, Manuel Braga da (1980). As Origens da Democracia Cristã e o Salazarismo, Lisboa: Presença.

Diário da Manhã (1941a). "O sr. Armando Cortesão! Um mentor?!...", 24 October.

Diário da Manhã (1941b). "Propaganda Séria e Propaganda Desonesta", 11 October.

Diário da Manhã (1941c). "Ponhamos acima de tudo o Interesse Nacional", 20 October.

Diário da Manhã (1941d). "A "B.B.C." e o sr. Cortesão", 25 October.

Egerton, Frederick Clement (1940). Salazar, Rebuilder of Portugal, London: Hodder \& Stoughton.

Egerton, Frederick Clement (1943). Reaction, Revolution or Re-Birth?, Ipswich: W.S. Cowell.

Hansard parliamentary debates, House of Commons, 19 December 1941, vol. $376,2255 \mathrm{~W}$.

Oliveira, César de (1987). Salazar e a Guerra Civil de Espanha, Lisboa: O Jornal.

Pinto, António Costa (Ed.) (2005). Contemporary Portugal, New York: Columbia University Press.

Ribeiro, Nelson (2005). A Emissora Nacional nos Primeiros Anos do Estado Novo (1933-1945), Lisboa: Quimera. 
Rosas, Fernando; Barros, Júlia Leitão de and Oliveira, Pedro de (1996). Armindo Monteiro e Oliveira Salazar. Correspondência Política 19261955, Lisboa: Editorial Estampa.

Salazar, Oliveira (1937). Discursos e Notas Políticas, Coimbra: Coimbra Editora.

O Século (1941). "Recidivas Perigosas", 17 October.

Winston, Brian (2005). Messages, London and New York: Routledge.

\footnotetext{
${ }^{1}$ At the start of the nineteen thirties, before becoming a dissident of the Estado Novo, Armando Cortesão held the post of Agent General of the Colonies, and was appointed Commissioner of the Portuguese Colonial Section at the International, Colonial, Maritime and Flemish Art Exhibition in Antwerp.

2 During the summer of 1938 Jaime and Armando Cortesão were both among those who put "Plan L" into motion. This plan consisted of reassembling all the military personnel exiled in Spain in order to initiate an operation to invade Portugal. This would supposedly take place with the help of the Spanish republican forces. Nevertheless, the advance of Franco in the Spanish civil war along with the USSR's condemnation of the operation frustrated the invasion plan. The preparation of the operation had been carefully monitored by the PVDE, who controlled informers among the exiles (Oliveira, 1987, pp. 275-278).

${ }^{3}$ These rumours are mentioned in several documents, namely: telegram from Salazar to Monteiro, 22 October 1941, Historic Diplomatic Archive, M.143 CP and letter from Monteiro to Salazar, 16 September 1941, in Rosas et al., 1996, p. 184

4 Salazar never questioned the Anglo-Portuguese alliance which ensured the British government's discreet support for his dictatorship. (Pinto, 2005, p. 29).

${ }_{5}^{5}$ There are several letters in which Armindo Monteiro speaks of Colonel Egerton as a friend of the Portuguese regime (Letters from Monteiro to Salazar, Historic Diplomatic Archive, M.97 CP). ${ }^{6}$ The BBC's success is confirmed by several sources namely: internal report of the Foreign Office, 1944, National Archives, FO 371/39616; letter from the Ministry of Information to Cadogan (F.O.), 18 September 1940, National Archives, FO 371/24493; report from Winch, January 1943, National Archives, FO 371/34691; BBC Survey of European AudiencesPortugal, BBC Written Archives, E2 198.
} 